\title{
CEO Constellation, Capital Structure, and Financial Performance
}

\author{
Hsien-Chang Kuo ${ }^{1} \&$ Lie-Huey Wang ${ }^{2}$ \\ ${ }^{1}$ Shih Chien University, Taipei, Taiwan \\ ${ }^{2}$ Ming Chuan University, Taipei, Taiwan \\ Correspondence: Lie-Huey Wang, Ming Chuan University, No. 250, Zhong-Shan N. Rd., Sec. 5, Taipei 11103, \\ Taiwan. Tel: 886-2-2882-4564 ext.2191
}

Received: July 21, 2015

Accepted: August 21, 2015

Online Published: September 4, 2015

doi:10.5430/ijfr.v6n4p76

URL: http://dx.doi.org/10.5430/ijfr.v6n4p76

This study is fully financial supported by National Science Council in Taiwan, the contract no.: NSC101-2410-H-147-010.

\begin{abstract}
Distinctive from prior research that emphasizes the influences of CEO demographic characteristics on corporate financial strategies, this study uses constellation as the proxy variables for CEO psychological traits and takes into consideration demographic characteristic variables to further analyze the relationship between CEO traits and corporate financial leverage, performance, and growth opportunity. This is an interesting issue worthy of study because shareholders and potential investors are always searching for CEOs that can create and increase values for the firms. The results show that there is a greater proportion of Leo CEOs in high-leverage firms, a greater proportion of Virgo CEOs in low-leverage and high-ROA firms, and a greater proportion of Pisces CEOs in both low- and high-MB-ratio firms. In addition, the CEOs with air-constellation are positively related to ROA. In general, fire-sign and earth-sign CEOs prefer high financial leverage, while air-sign CEOs are averse to such; fire-sign and air-sign CEOs have positive influences on firm profitability, while earth-sign CEOs have negative influences. Moreover, cash compensation will reduce the positive effect of air-sign CEOs on ROA.
\end{abstract}

Keywords: CEO traits, constellation, debt ratio, MB ratio

\section{Introduction}

The chief executive officer (CEO) is the primary decision-maker in a company and is an important leader in planning the company's strategic directions (Calori, Johnson, \& Sarnin, 1994; Certo, Lester, Dalton, \& Dalton, 2006). A CEO's management style affects the formation and execution of the firm's strategies (Jensen \& Zajac, 2004), and his/her managerial characteristics also affect the firm's investment decisions, financial performance and firm value (Malmendier \& Tate, 2005; Coel \& Thakor, 2008; Colbert, Barrick, \& Bradely, 2014). According to the upper-echelon perspective, the observable demographic characteristics of specific managers, such as age, tenure, education, prior work experience and functional backgrounds, are all important factors that can influence firm decisions and performance (Hambric \& Mason, 1984; Custodio \& Metzger, 2014; Nguyen, Hagendorff, \& Eshraghi, 2015).

Peterson, Martorana, Smith, and Owens (2003) and Kisfalvi and Pitcher (2003) discussed how the CEO's personality influences the decision-making process of the top management teams (TMTs) and the subsequent impact on firm performance. Bertran and Schoar (2003) suggested that the heterogeneity in a firm's investments, financing, and organizational practice can be explained by the fixed effect of the manager. In other words, the psychological biases or personality traits of the manager are important factors influencing the differences in the firm's decisions (Baccar, Ben Mohamed, \& Bouri, 2013; Ben Fatma, Ben Mohamed, \& Boudabouss, 2013; Graham, Harvey, \& Puri, 2013; Ben Mohamed, Souisssi, Baccar, \& Bouri, 2014). Several scholars have pointed out that the CEO's managerial orientation has significant impact on the diversification strategy of the corporation (Papadakis, 2006; Martinez-Campillo \& Fernandez-Gago, 2011).

Many studies in behavioral finance have found that some specific manager traits, such as gender, age, tenure, educational background and career experience, are related to decision-making behavior (Barber \& Odean, 2001; 
Bertrand \& Schoar, 2003; Malmendier \& Tate, 2005; Matta \& Beamish, 2008; Antia, Pantalis, \& Park, 2010; Lin, Lin, Song, \& Li, 2011; Buyl, Boone, Hendriks, \& Matthyssens, 2011; Ben Mohamed, Baccar, Fairchild, \& Bouri, 2012). In addition, in a moral hazard model created by information asymmetry, the manager prefers short-term results out of self-interest and sacrifices long-term optimal results for the company (Jensen \& Meckling, 1976). In other words, these decisions are short-term decisions that fulfill personal optimization from the manager's personal perspectives; but they might be sub-optimal from the company's perspectives. Hirshleifer and Thakor (1992) pointed out that the managers may choose myopic investment out of reputational concerns for their personal ability. According to the hubris hypothesis of Roll (1986), overconfident CEOs aggressively make acquisitions (Malmendier \& Tate, 2008; Ferris, Jayaraman, \& Sabherwal, 2013). Moreover, overconfident CEOs overestimate the return on investment plans, and, given abundant internal funds, tend to overinvest. However, when external financing is required, overconfident managers believe that outside market has undervalued their companies, so they often forego mergers and underinvest (Malmendier \& Tate, 2005).

Recent studies show that corporate capital structure decisions do not correspond with the behavior model of rational managers; it is a myth that remains to be clarified (Baker \& Wurgler, 2002; Welch, 2004). The trade-off theory (Myers, 2001), established on the assumption of managerial rationality, has argued that the personal behavior of the manager is not reflected in corporate capital structure decisions. However, the agency theory proposed by Jensen and Meckling (1976) presents an opposite view, suggesting that that the self-interested behaviors of CEOs may damage the interests of the company as a whole. Other studies in behavioral finance have discussed the impacts of the manager's demographic characteristics and psychological traits on corporate financing decisions. Demographic characteristics include age, tenure, educational background, and career experience (Hambrick \& Mason, 1984; Berger, Ofek, \& Yermack, 1997; Pegels \& Yang, 2000; Graham \& Harvey, 2001; Barker \& Mueller, 2002; Bertrand \& Schoar, 2003; Chen, Hsu, \& Huang, 2010; Strebulaev \& Yang, 2013) while psychological traits include risk aversion, time preference, and overconfidence (Heaton, 2002; Malmandier \& Tate, 2005, 2008; Graham, Harvey, \& Puri, 2008; Landier \& Thesmar, 2009; Malmendier, Tate, \& Yan, 2011). The aforementioned empirical studies have found significant correlations between corporate capital structure and traits of CEOs or TMTs. Therefore, behavioral finance can explain the puzzle behind capital structure decisions better than traditional finance (Subrahmanyam, 2007).

Recently, there are many papers suggest that CEOs' personality matter. For instance, CEO charisma and firm performance interact in predicting leader retention (Jacquart \& Antonakis, 2015) and CEO charisma is related to firm performance via its effect on the transformational leadership climate within an organization and the firm's organizational identity strength (Boehm, Dwertmann, Bruch, \& Shamir, 2015). Moreover, the companies led by narcissistic CEOs exhibit higher levels of entrepreneurial orientation and experience greater variability in firm performance (Wales, Patel, \& Lumpkin, 2013), and the narcissistic personality characteristics of top executives affect financial performance measures through their decisions and influence over the firm's operational activities (Olsen, Dworkis \& Young, 2014). In addition, according to the matching theory, CEOs that do not match their firms will leave, while CEOs that match will stay (Allgood \& Farrell, 2003). Granham et al. (2008) suggested that it is the CEO's behavioral traits that match the firm, i.e., a CEO will choose a firm that matches his personal traits, or a firm will employ a CEO with specific traits it demands. For example, firms that prefer risk-taking CEOs have higher degree of risks; high-growth firms prefer risk-taking CEOs; young CEOs are confident, prefer risk-taking, and tend to work in high-growth firms (Navaretti, Castellani, \& Pieri, 2014); CEOs with high risk-taking tendencies and tolerance for uncertainties are more suitable for high-tech initial public offering (IPO) firms (Nelson, 2003); the financial expert CEOs tend to be hired by more mature firms (Custodio \& Metzger, 2014); and, the firms and CEOs match according to their leverage preferences (Cronqvist, Makhija, \& Yonker, 2012). In practice, when hiring employees, many firms not only evaluate the demographic characteristics of recruits, but also take into consideration their psychological traits, in order to select employees that match with the company's profile. For example, it is believed that the twelve Zodiac Signs are associated with different kinds of personality traits (See Appendix 1). An Aries person is characterized by high tolerance, pioneering spirit, and leadership. Taurus is practical, enduring, and cautious. Gemini is full of curiosity, intellectual, calm, courageous, and witty. Cancer is sensitive, reserved, and traditional. Leo is trustworthy, self-confident, egoistic, and power hungry. Virgo is diligent, precise, practical, and perfectionist. Libra is rational, graceful, and diplomatic. Scorpio is observant, determined, and innovative. Sagittarius is straightforward, freedom-loving, optimistic, and adventurous. Capricorn is thoughtful, patient, cautious, and practical. Aquarius is independent, courageous, and innovative. Pisces is self-sacrificing, dependent, sensitive, and talented. Since the 
personality traits mentioned above may have influence on the employees' behavior in the organization and thus have impact on company performance, some companies take into consideration whether traits of the employees' Zodiac Signs match with their positions.

Moreover, observing the trends in political and financial world, take for example the "Business People of the Year 2011" published by Business Today in December, 2011, and putting aside the commercial appeal of Business Today, reveals that, in terms of the method of selection and the index it uses, its categorization represents respectively different managerial traits for different aspects of corporate governance, with matching birthdate and astrological Zodiac Signs, which might be an indication of the phenomenon in the field or the business world (see Appendix 2). For example, Tim Cook, the CEO of Apple Inc. in USA, is a Scorpio. Masayoshi Son, CEO of Softbank in Japan, is a Leo. And in Taiwan, Cher Wang, Chairwoman of HTC, is a Virgo. Sean Chen, former Premier of the Republic of China, is a Libra. Perng Fai-nan, Governor of the Central Bank of Taiwan, is a Scorpio. In other words, it might be suggesting that there is a certain degree of correlation between their Zodiac Signs and their performance in the positions. Therefore, statistical analysis of the influences of CEO traits, including their Zodiac Signs, on capital structure and financial decisions is a cross-disciplinary study that combines academic research and actual practice. Moreover, it is a fun subject of research interests.

Previous studies reveal that the demographic characteristics and psychological traits of CEOs influence their behaviors and performance, resulting in heterogeneity in strategic decisions of firms. Since it is not easy to obtain the data on CEO psychological traits through observations, and neither is it possible to accurately measure and quantify it, most studies emphasize the influences of demographic characteristics, which is easier to obtain. To supplement prior research, this study uses character traits represented by Zodiac Signs as proxy variables for the inner psychological traits of the CEOs in order to analyze the heterogeneity presented by CEOs' psychological traits and its correlation with the firms' financial strategies and performances. There is much discussion on the influences of CEO personality traits on the capital structure and profitability performance of firms; it is an issue of both academic and practical concern. This study uses the personality traits represented by the Zodiac Signs of CEOs as a starting point for research to observe how the personal characteristics of CEOs, who are decision-makers of companies, influence the capital structure and performance of firms. This is a perspective with new ways of thinking and has academic and practical value. Moreover, this is an interesting subject worthy of study because shareholders and potential investors are always looking for suitable CEOs that can create and increase value for the firms. The findings will also contribute to the discussion on influences of CEO personality traits on corporate capital structure and performance.

The rest of the paper is organized as follows. Section 2 reviews previous studies, focusing on literature related to influences of CEO traits on capital structure and performance. Section 3 presents the methodology, data source, empirical model, and variable definitions. Empirical analysis results are discussed in Section 4. Section 5 contains the conclusion of this study.

\section{Literature Review}

\subsection{CEO Traits and Capital Structure}

Traditional financial theories have discussed the relationship between manager and corporate capital structure decisions from classical perspectives. In general, traditional corporate financial theories, assuming managerial rationality, suggest that the managers' personal behaviors do not influence corporate capital structure decisions. For example, the trade-off theory (Myers, 2001) assumes that managers will give priority to the interests of shareholders as a whole (Leland \& Toft, 1996; Goldstein, Ju, \& Leland, 2001; Hennessy \& Whited, 2005; Hackbarth, Hennessy, \& Leland, 2007; Strebulaev, 2007); therefore, the managers' personal traits do not have any impact on corporate capital structure decisions. However, the agency theory suggests that CEO as an agent for the company may sacrifice corporate interest to maximize personal gains out of self-interested rational behavior (Jensen \& Meckling, 1976).

Many empirical studies have discussed the influences of manager traits on corporate financial decisions (Berger et al., 1997; Graham \& Harvey, 2001; Bertrand \& Schoar, 2003). Berger et al. (1997) found that entrenched managers will avoid debt-financing for companies. Baker and Wurgler (2002), on the basis of the rationality perspective, suggested that choosing debt-equity financing is the result of weighing interest tax shields and bankruptcy cost, and is influenced by the manager's view on whether their stock has been undervalued by the market. Welch (2004) proposed that corporate capital structures do not change with fluctuations in the stock market; this phenomenon is inconsistent with the rational assumption of capital structure decisions. Subrahmanyam (2007) suggested that the 
behavioral models developing according to actual personal behaviors can better explain the puzzle behind capital structure decisions.

Bertran and Schoar (2003) discussed the influences of managerial fixed effects on corporate decisions and found that CEOs with some particular traits tend to actively use debt-financing or dividend policies. Granham et al. (2008) analyzed psychological traits of managers such as risk aversion, time preference and optimism, and their relationship with corporate financial policies, and found that CEO personality traits or career path characteristics have influence on corporate capital structure. Heaton (2002) and Malmendier and Tate (2005) reported that optimistic or overconfident managers believe that their companies' stocks are being undervalued by the market and tend to use internal funds or debt-financing to replace equity financing. In other words, optimistic or overconfident managers will follow the pecking order theory to minimize external funding costs through decreasing risky equity financing. In addition, some empirical studies have found that overconfident CEOs can impact the companies' levels of debt financing. For example, Hackbarth (2008) found that optimistic and/or overconfident managers choose higher debt levels and issue new debt more often but need not follow a pecking order. Landier and Thesmar (2009) observed that overconfident CEOs prefer higher amount of short-term debt financing; Malmendier and Tate $(2005,2008)$ indicated that overconfident CEOs underestimate bankruptcy risk of the firm and choose aggressive financing policies, i.e., higher financial leverage ratio. Malmendier et al. (2011) found that overconfident CEOs tend to reduce leverage and the CEOs' early-life experiences influence their risk-taking behaviors and financial decision choices.

The study of Chen et al. (2010) suggested that TMT traits significantly influence the firm's financing decisions. Young CEOs prefer high-risk strategies while senior managers prefer conservative ones, the same finding as those of Hambrick and Mason (1984), Pegels and Yang (2000), and Barker and Mueller (2002). Therefore, older CEOs tend to avoid risks, and, out of concern for personal positions and financial gains, prefer conservative capital structure decisions, while younger CEOs prefer higher amount of debt-financing. In addition, Custodio and Metzger (2014) found that firms with financial expert CEOs hold more debt, and Hu and Liu (2015) shown that firms with CEOs who have more diverse career experience exploit more outside funds.

\subsection{CEO Traits and Firm Performance}

Previous studies have found that CEO demographic characteristics are highly correlated with corporate performance. Peterson, Walumbwa, Byron, and Myrowitz (2009) stated that the positive psychological traits of CEOs positively relate to transformational leadership which is more strongly related to firm performance. Mohamed, Jarboui, Baccar, and Bouri (2015) indicated that CEOs' personal characteristics can largely affect firm value and policy makers are invited to provide the optimal CEOs' characteristics that can avoid such distortions on firm value. Nguyen et al. (2015) found that age, education, and the prior work experience of executives create shareholder wealth while gender is not linked to measureable value effects. Some studies have pointed out that age can influence a person's cognition, belief and human relationship network (Richard \& Shelor, 2002), and that aging can lead into accumulation of personal experience, thus influencing the person's attitude toward optimism and risks (Ben Mohamed et al., 2012). For example, younger CEOs may aggressively reform company strategies or pursue high-risk strategies, while older CEOs are more conservative, tend to be pessimistic toward new technologies and prefer simpler solutions (Hambrick \& Mason, 1984; Pegels \& Yang, 2000; Barker \& Mueller, 2002). Therefore, CEO age is highly correlated with corporate strategy and performance (Wiersema \& Bantel, 1992; Weinzimmer, 1997). In addition, some studies have found that CEO age is related to the horizon problem. For example, Dechow and Sloan (1991), Barker and Muller (2002), and Matta and Beamish (2008) all found that CEOs close to retirement have higher degree of risk aversion and will reduce R\&D investment. Conversely, younger CEOs, out of consideration for position and financial gains, have broader long-term horizon and higher risk tolerance, and therefore tend to increase R\&D investment. Ryan and Wiggins (2002) pointed out that corporate R\&D investment and CEO age present a non-linear inverted U-shaped correlation.

Other relevant empirical studies have found that tenure affects the CEO's willingness to take risks (Barker \& Mueller, 2002). Jensen and Meckling (1979) pointed out that CEOs with shorter tenure will set up higher hurdle rate and tend to underinvest. Hirshleifer (1993) suggested that CEOs with shorter tenure, out of personal reputational concern, will focus on short-term performance and be unwilling to invest in R\&D with higher risks. Myopic managers prefer investment plans with shorter payback periods due to concerns for reputation in labor market and job security (Hirshleifer \& Thakor, 1992). Miller (1991), Hambrick and Fukutomi (1991), Thomas, Litschert, and Ramaswamy (1991), Hambrick, Geletkanycz, and Fredirckson (1993) and Barker and Muller (2002) all indicated that long-tenured CEOs might neglect environmental changes or be out of touch with organizational environment, and refuse changes 
and innovative or risky investments, because of desires to maintain status quo, concerns for personal job stability, or empire-building ambitions; thus causing negative impacts on company performance and becoming an obstacle for company growth.

According to the CEO-life-cycle model, CEOs with longer tenure can acquire bargaining power through contributions to firm performance or through becoming an internal director. This effect may reduce board supervision of CEO. Therefore, longer tenure reduces the risk of termination for the CEO (Shleifer \& Vishny, 1989; Hermalin \& Weisbach, 1998). In addition, according to the matching theory, CEOs that are poor matches for the company will leave the position, while highly matching CEOs will stay. Therefore, at the beginning of the CEO's tenure, the risk of termination will increase, but the risk of termination will decrease with increasing length of tenure for the CEO (Allgood \& Fareell, 2003). Brookman and Thistle (2009) used survival analysis to estimate the hazard function for CEO tenure and examine how the increment of risk of termination is related to the CEO's length of tenure; their study found that the longer the CEO's tenure is, the better the company performs.

Antia et al. (2010) used CEO tenure and age as proxy variables for CEO decision horizons and analyzed the influences of CEO decision horizons on market evaluation of the company. The results show that shorter decision horizons generate higher agency costs and information risks, which may lower the firm's market value. However, interests of longer-tenured CEOs are more aligned with those of shareholders; this may lead to increase in market's valuation of the firm (Jarboui, Forget, \& Boujelbene, 2014).

\section{Methodology}

\subsection{Data Source}

This study collects the S\&P 500 database using 129 non-financial firms from 2009 to 2011 . The samples include firms from the mining industry ( 5 firms), construction industry (2 firms), manufacturing industry (70 firms), transportation, communication, electricity, gas and sanitary service industries ( $23 \mathrm{firms})$, wholesale trade (1 firm), retail trade (14 firms), services (11 firms), and other industries (3 firms). The CEO demographic characteristics data (including age, tenure, gender, and pay) are mainly taken from EXCUCOMP database; the CEO's date of birth data is obtained through Who's Who; the financial data are obtained from COMPUSTAT. The Zodiac Signs of the CEOs are calculated on the basis of their dates of birth, checked through en.wikipedia.org, and then double-checked one-by-one to confirm that the names and the companies match.

\subsection{Empirical Model}

Since both cross-sectional and time-series data exist in the empirical data of this study, in order to avoid the problem of cross-sectional self-effect of individual companies being neglected by the ordinary least square method, we employ panel data random effect regression model for the empirical analysis of the relationship between CEO characteristics, capital structure, and firm performance. The empirical model is as follows:

$$
\begin{aligned}
& D E B T_{i t}=\alpha_{i}+\sum_{k=1}^{3} \beta_{k} \text { Constell }_{i t}+\phi_{1} A G E_{i t}+\phi_{2} P A Y_{i t}+\gamma_{1} \text { LnTA }_{i t}+\gamma_{2} R O A_{i t}+\gamma_{3} M B_{i t}+\varepsilon_{i t} \\
& R O A_{i t}=\alpha_{i}+\sum_{k=1}^{3} \beta_{k} \text { Constell }_{i t}+\phi_{1} A G E_{i t}+\phi_{2} P_{i t}+\gamma_{1} \text { LnTA }_{i t}+\gamma_{2} D E B T_{i t}+\gamma_{3} M B_{i t}+\varepsilon_{i t} \\
& M B_{i t}=\alpha_{i}+\sum_{k=1}^{3} \beta_{k} \text { Constell }_{i t}+\phi_{1} A G E_{i t}+\phi_{2} P_{i t}+\gamma_{1} \text { LnTA }_{i t}+\gamma_{2} D E B T_{i t}+\gamma_{3} R O A_{i t}+\varepsilon_{i t}
\end{aligned}
$$

where $D E B T$ is debt ratio, representing the proxy variable for capital structure of the firms, calculated by dividing total liabilities by total assets; $R O A$ is return on assets, representing the proxy variable for company performance, calculated by dividing the company's net income after tax by total assets; and $M B$ is market-to-book ratio, representing the proxy variable for the company's future growth opportunity, calculated by dividing market price of equity by book value of equity. The model's independent variable, Constell, is the constellation category of the CEOs; this study classifies the 12 Zodiac Signs into 4 categories: fire, earth, air, and water, creating 3 dummy variables. $A G E$ is the CEO's age. $P A Y$ is the CEO's cash compensation, including salary and bonus. LnTA is the company's total assets, representing the proxy variable for firm size, calculated by taking the natural logarithm of total assets. Table 1 shows the operational definition of variables. 
Table 1. Operational definition of variables

\begin{tabular}{|c|c|c|}
\hline Variable & Symbol & Definition \\
\hline Debt Ratio & DEBT & Debt Ratio $=($ total debts $\div$ total assets $) \times 100 \%$ \\
\hline Return on Assets & ROA & $\mathrm{ROA}=($ net income after tax $\div$ average total assets $) \times 100 \%$ \\
\hline Constellation type & Constell & $\begin{array}{l}\text { Divide the } 12 \text { Zodiac Signs into } 4 \text { elemental categories: fire, earth, air and } \\
\text { water; and create } 3 \text { dummy variables: Fire, Dust, Wind. For firms with } \\
\text { CEOs born under the signs of Ares, Leo, and Sagittarius, Fire }=1 \text {; } \\
\text { otherwise, Fire }=0 \text {. For Taurus, Virgo, and Capricorn, Dust }=1 \text {; otherwise, } \\
\text { Dust }=0 \text {. For Gemini, Libra and Aquarius, Wind }=1 \text {; otherwise, Wind }=0 \text {. }\end{array}$ \\
\hline Growth Opportunity & MB & $\begin{array}{l}\text { Use market-to-book ratio of firm equity as the proxy variable for the firm's } \\
\text { growth opportunity; } \mathrm{MB}=\text { market value of equity } \div \text { book value of equity. }\end{array}$ \\
\hline Firm Size & LnTA & $\begin{array}{l}\text { Use the total assets (TA) of the firm as the proxy variable for firm size; } \\
\text { LnTA = natural logarithm of the total assets of the firm. }\end{array}$ \\
\hline Age & AGE & Age of the CEO of the firm. \\
\hline Cash pay & PAY & Cash compensation of $\mathrm{CEO}=$ salary + bonus. \\
\hline
\end{tabular}

\section{Empirical Results}

\subsection{Data Analysis}

The descriptive statistics of the empirical variables are exhibited in Table 2. The results show that the average debt ratio of the 129 firms is $60.09 \%$; the average ROA is $5.96 \%$; the average MB ratio is 3.02 ; the average total assets is USD 47,219 million; the average CEO age is 70; the average cash pay for the CEO is USD 2,112,000. In addition, according to the minimum, maximum and standard deviation of the variables, the sample firms have high variability for all the variables.

Table 2. Descriptive statistics

\begin{tabular}{lllll}
\hline Variable & Average & Minimum & Maximum & Std. Dev. \\
\hline Debt ratio & 60.09 & 19.78 & 97.76 & 16.02 \\
ROA & 5.96 & -16.14 & 76.811 & 6.58 \\
MB ratio & 3.02 & 0.01 & 90.55 & 5.35 \\
TA (million USD) & 47219.44 & 142.00 & 781818.00 & 85904.61 \\
Age & 69.77 & 44.00 & 95.00 & 8.93 \\
Cash pay (thousand USD) & 2112.84 & 46.11 & 16700.00 & 2236.13 \\
\hline
\end{tabular}

This table shows the results of descriptive statistics of variables. Debt ratio $=$ (total debts $\div$ total assets) $* 100 \%$. ROA is return on assets $=$ (net income after tax $\div$ average total assets $) * 100 \%$. MB ratio is market-to-book ratio $=$ market value of equity $\div$ book value of equity. TA is the total assets. AGE denotes age of the $\mathrm{CEO}$ of the firm. Cash pay is the CEO's cash compensation $=$ salary + bonus .

This study uses mode to observer the CEO distribution of the 129 samples and finds that Virgo CEOs constitute the majority among the 12 Zodiac Signs; CEOs with earth-sign constitute the majority according to the four elemental classification. CEOs with fixed modality are the majority according to the three modality classification.; and CEOs with negative polarity are the majority according to the two polarity classification of Zodiac Signs. Such findings indicate that the 129 firms prefer CEOs with Zodiac Signs characterized by leadership, innovativeness, stability, intelligence, optimism and cautiousness. For the classification and characteristics of the Zodiac Signs, please refer to Appendices 1 and 2. Furthermore, the debt ratio, ROA, and MB ratio are sorted in ascending order, and 129 firms are divided into three groups. The first $25 \%$ is classified into the Low group, the next $50 \%$ is classified into the Middle group, and the last $25 \%$ is classified into the High group. And then uses mode to observe the Zodiac Signs in each group. The mode distribution data of CEO Zodiac Signs in Low, Middle, and High groups are presented in Table 3. 
Table 3. Mode distribution of CEO constellation traits in three sub-groups

\begin{tabular}{clccc}
\hline Sub-group & Constellation & Debt Ratio & ROA & MB Ratio \\
\hline \multirow{6}{*}{ Low } & 12 Zodiacs Signs & Virgo & Taurus & Pisces \\
& 4 Elements & Earth & Water & Water \\
& 3 Modalities & Mutable & Fixed & Fixed \\
& 2 Polarities & Negative & Negative & Negative \\
\hline \multirow{5}{*}{ Middle } & 12 Zodiacs Signs & Pisces & Leo & Virgo \\
& 4 Elements & Water & Earth & Earth \\
& 3 Modalities & Mutable & Fixed & Fixed \\
& 2 Polarities & Negative & Negative & Negative \\
\hline \multirow{6}{*}{ High } & 12 Zodiacs Signs & Leo & Virgo & Pisces \\
& 4 Elements & Fire & Air & Air \\
& 3 Modalities & Fixed & Mutable & Mutable \\
& 2 polarities & Positive & Positive & Positive \\
\hline
\end{tabular}

This study sorts the debt ratios, ROA, and MB ratios of the 129 firms from low to high to divide the samples into Low, Middle, and High groups. The first $1 / 4$ firms belong to the Low group; the next $1 / 2$, Middle, and the last $1 / 4$, High. Then mode is employed to observe the most frequent Zodiac Signs in the groups. According to the 4 Elements, the 12 Zodiac Signs are divided into groups of Fire signs, Earth signs, Air signs, and Water signs. According to the 3 Modalities, the 12 Zodiac Signs are divided into Cardinal, Fixed, and Mutable groups. According to the 2 Polarities, the 12 Zodiac Signs are divided into Positive and Negative Groups. Debt ratio $=$ (total debts $\div$ total assets) $* 100 \%$. ROA is return on assets $=$ (net income after tax $\div$ average total assets $) * 100 \%$. MB ratio is market-to-book ratio $=$ market value of equity $\div$ book value of equity.

Overall, the mode distribution of Zodiac Signs shows that, firms with higher debt ratio, $R O A$, and $M B$ ratio have CEOs with positive signs; while firms with lower debt ratio, $R O A$ and $M B$ ratio have CEOs with negative signs. From the perspective of the 12 Zodiac Signs, most firms with high debt ratio have Leo CEOs; most firms with low debt ratio and high $R O A$ have Virgo CEOs; and Pisces CEOs show bipolar influences for the $M B$ ratio of firms. From the perspective of elements and modalities, firms with fire-sign or fixed-modality CEOs have higher debt ratios; firms with earth-sign and water-sign or mutable-modality CEOs have lower debt ratios. Firms with air-sign or mutable-modality CEOs have higher $R O A$ and $M B$ ratios. Firms with water-sign and earth-sign or mutable-modality CEOs have lower $R O A$ and $M B$ ratios.

This study further uses one-way ANOVA to test the differences between debt ratio, $R O A, M B$ ratio, and CEO pay of the four astrological categories; the results are presented in Table 4. As can be seen, there are significant differences between debt ratio, ROA and CEO pay. Comparing the means of the firms among the four astrological categories shows that, in terms of debt ratio, firms with fire-sign CEOs have the highest debt ratio, while firms with air-sign CEOs have the lowest debt ratio; in terms of $R O A$, air signs have the highest $R O A$, while earth signs or water signs have lower $R O A$; in terms of CEO pay, fire-sign CEOs have the highest pay, while air-sign CEOs have the lowest pay.

Table 4. One-way ANOVA

\begin{tabular}{llllll}
\hline Variable & Fire Signs & Earth Signs & Air Signs & Water Signs & F-test \\
\hline Debt ratio & 63.25 & 59.36 & 56.99 & 61.03 & $2.509^{* *}$ \\
ROA & 6.68 & 4.94 & 7.62 & 4.89 & $4.141^{* * *}$ \\
MB ratio & 3.84 & 3.20 & 2.90 & 2.21 & 1.496 \\
Cash pay & 49187.76 & 31197.27 & 27218.08 & 30785.29 & $2.487^{* *}$ \\
\hline Firms(Observations) & $29(87)$ & $36(108)$ & $31(93)$ & $33(99)$ & \\
\hline
\end{tabular}

Fire signs include Aries, Leo, and Sagittarius; Earth signs include Taurus, Virgo, and Capricorn; Air signs include Gemini, Libra, and Aquarius; Water signs include Cancer, Scorpio, and Pisces. $* *$ and $* * *$ represent $5 \%$ and $1 \%$ statistical significance level, respectively. Debt ratio $=($ total debts $\div$ total assets $) * 100 \%$. ROA is return on assets $=$ (net income after tax $\div$ average total assets) $* 100 \%$. MB ratio is market-to-book ratio $=$ market value of equity $\div$ book value of equity. Cash pay is CEO's cash compensation $=$ salary + bonus. 


\subsection{CEO Constellation Trait Analysis}

This study uses panel data random effect model to test the relationship between CEO constellation traits and corporate financial leverage, profitability, and growth opportunity, respectively; the test results are displayed in Table 5. As the findings can be seen, Model (1) shows that CEO constellation traits do not present significant influence on the firms' debt ratios and $M B$ ratios; only air signs are significantly positively correlated with $R O A$. Overall, fire-sign or earth-sign CEOs prefer high financial leverage, while air-sign CEOs prefer low financial leverage. Fire-sign or air-sign CEOs have positive influences on firm profitability, while earth-sign CEOs have negative influences on profitability. Moreover, $\mathrm{CEO}$ cash compensation is significantly negatively correlated with debt ratio and $R O A$, indicating that while cash compensation may prevent CEOs from raising financial leverage, but it might not benefit to a firm's $R O A$.

Table 5. Random effect regression analysis

\begin{tabular}{lllllll}
\hline \multirow{2}{*}{ Variable } & \multicolumn{2}{c}{ DEBT } & \multicolumn{2}{c}{ ROA } & \multicolumn{2}{c}{ MB } \\
\cline { 2 - 6 } & Model (1) & Model (2) & Model (1) & Model (2) & Model (1) & Model (2) \\
\hline Fire & 0.371 & 0.331 & 1.671 & 1.914 & 0.908 & -0.264 \\
Dust & 0.036 & -0.555 & -0.148 & 0.959 & 1.043 & 0.237 \\
Wind & -0.750 & 1.257 & $2.254^{* *}$ & $4.460^{* * *}$ & 0.583 & 0.086 \\
AGE & 0.022 & 0.007 & -0.004 & -0.004 & 0.023 & 0.015 \\
PAY & $-0.946^{* *}$ & $-1.128^{* *}$ & $-0.641^{*}$ & -0.146 & 0.307 & -0.060 \\
Fire x Dpay & & 0.275 & & -0.316 & & 2.028 \\
Dust x Dpay & & 2.354 & & -1.682 & & 1.460 \\
Wing x Dpay & & -2.371 & & $-3.765^{* *}$ & & 0.640 \\
LnTA & $3.018^{* * *}$ & $3.110^{* * *}$ & $0.753^{* *}$ & $0.866^{* * *}$ & -0.312 & -0.348 \\
DEBT & & & $-0.122^{* * *}$ & $-0.118^{* * *}$ & $0.124^{* * *}$ & $0.122^{* * *}$ \\
ROA & $-0.131^{* * *}$ & $-0.145^{* * *}$ & & & $0.181^{* * *}$ & $0.184^{* * *}$ \\
MB & $0.361^{* * *}$ & $0.358^{* * *}$ & $0.221^{* * *}$ & $0.216^{* * *}$ & & \\
Constant & $35.537^{* * *}$ & $11.684^{* * *}$ & $9.388^{*}$ & 4.184 & $-7.050^{*}$ & -3.236 \\
Adj R & 0.0738 & 0.0753 & 0.1515 & 0.1526 & 0.1681 & 0.1808 \\
\hline
\end{tabular}

This study divides the 12 Zodiac Signs into 4 elemental groups: fire signs, earth signs, air signs and water signs; and creates 3 dummy variables for them: Fire, Dust, and Wind, respectively. For firms with CEOs born under the signs of Ares, Leo, and Sagittarius, Fire $=1$; otherwise, Fire $=0$. For those under Taurus, Virgo, and Capricorn, Dust $=1$; otherwise, Dust $=0$. For those under Gemini, Libra and Aquarius, Wind $=1$; otherwise, Wind $=0$. AGE denotes age of the CEO of the firm. PAY denotes cash compensation for the CEO = salary + bonus. This study uses the median of the CEO cash pay of all samples as the basis for distinguishing the level of cash compensation: if the CEO's pay is higher than the median, Dpay $=1$; otherwise, Dpay $=0$. LnTA is the natural logarithm of a firm's total assets. DEBT is debt ratio $=$ (total debts $\div$ total assets) $* 100 \%$. ROA is return on assets $=$ (net income after tax $\div$ average total assets) $* 100 \%$. MB is market-to-book ratio $=$ market value of equity $\div$ book value of equity. Constant is the intercept item of random effect model. *,**, and *** represent $10 \%, 5 \%$, and $1 \%$ statistical significance level, respectively.

This study further includes the interaction of CEO constellation and cash pay to examine whether CEO cash compensation has influence on the relationships between CEO constellation traits and financial leverage, profitability, and growth opportunity. The median of CEO cash pay from all samples is used as a basis for dividing cash compensation into high and low. A dummy variable is created; i.e., if a CEO's cash compensation is larger than the median, Dpay $=1$; otherwise, Dpay $=0$. Model (2) shows that only ROA is influenced by air-sign traits and that they are significantly correlated. However, the regression coefficient of the interaction of air sign and cash pay presents a negative correlation, indicating that high cash compensation will weaken the positive effect of Air-sign CEO on firms' ROA.

\section{Conclusion}

According to the upper-echelon perspective, the demographic characteristics of managers are important factors influencing corporate governance and performance. From the perspective of financial behaviors, corporate financing decisions are significantly influenced by $\mathrm{CEO}$ demographic characteristics and psychological traits. Distinctive from prior research that emphasizes the influences of CEO demographic characteristics on corporate financial strategies, 
this study uses constellation traits as the proxy variables for CEO psychological traits and takes into consideration demographic characteristic variables to further analyze the relationship between CEO traits and corporate financial leverage, performance, and growth opportunity to fill in the gaps of related literature. This is an interesting issue worthy of study because shareholders and potential investors are always searching for CEOs that can create and increase values for the firms.

This study takes 129 non-financial S\&P 500 firms from 2009 to 2011 as samples and uses the panel data random effect regression model to analyze the relationship between CEO constellation traits and corporate financial leverage, performance, and growth opportunity. The results show that most firms with high financial leverage have Leo CEOs; most firms with low debt ratio and high ROA have Virgo CEOs; and Pisces CEOs have bipolar performance for the $\mathrm{M} / \mathrm{B}$ ratio of the firms. In addition, air constellations are positively correlated with ROA. Overall, fire-sign and earth-sign CEOs prefer high financial leverage, while air-sign CEOs prefer low financial leverage; fire-sign and air-sign CEOs have positive influences on firm profitability, while earth-sign CEOs have negative influences. Finally, we also find that the high cash compensation has negative influence on the performance of air-sign CEOs in terms of ROA.

Since this study emphasized the influences of CEO constellation traits, in the future, we can take into consideration the education background, career experience, and CEO position or identity traits (e.g., if the CEO is the founder or if dual positionality exists for the CEO). Moreover, further analysis may include the interaction effect of corporate governance mechanism and CEO constellation traits.

\section{References}

Allgood, S., \& Farrell, K. A. (2003). The Match between the CEO and the Firm. Journal of Business, 76(2), 317-341. http://dx.doi.org/10.1086/367752

Antia, M., Pantalis, C., \& Park, J. C. (2010). CEO Decision Horizon and Firm Performance: An Empirical Investigation. Journal of Corporate Finance, 16(3), 288-301. http://dx.doi.org/10.1016/j.jcorpfin.2010.01.005

Baccar, A., Ben Mohamed, E., \& Bouri, A. (2013). Managerial Overconfidence and Board Characteristics: Toward a New Role of Corporate Governance. Australian Journal of Basic and Applied Sciences, 7(7), 287-301.

Baker, M. P., \& Wurgler, J. (2002). Market Timing and Capital Structure. Journal of Finance, 57(1), 1-32. http://dx.doi.org/10.1111/1540-6261.00414

Barber, B., \& Odean, T. (2001). Boys Will Be Boys: Gender, Overconfidence, and Common Stock Investment. Quarterly Journal of Economics, 116(1), 261-292. http://dx.doi.org/10.1162/003355301556400

Barker, V., \& Mueller, G. (2002). CEO Characteristics and Firm R\&D Spending. Management Science, 48(6), 782-801. http://dx.doi.org/10.1287/mnsc.48.6.782.187

Ben Fatma, E., Ben Mohamed, E., \& Boudabouss, S. (2013). Entrepreneurship Theory: From Rational to Behavioral Theory. International Journal of Contemporary Business Studies, 4(5), 72-89.

Ben Mohamed, E., Baccar, A., Fairchild, R., \& Bouri, A. (2012). Does Corporate Governance Affect Managerial Optimism: Evidence from NYSE Panel Data Firms. International Journal of Euro-Mediterranean Studies, 5(1), 41-56. http://dx.doi.org/10.1007/s40321-012-0004-6

Ben Mohamed, E., Souissi, M. N., Baccar, A., \& Bouri, A. (2014). CEO's Personal Characteristics, Ownership and Investment Cash Flow Sensitivity: Evidence from NYSE Panel Data Firms. Journal of Economics, Finance and Administrative Science, 19(37), 98-103. http://dx.doi.org/10.1016/j.jefas.2014.10.002

Berger, P., Ofek, E., \& Yermack, D. (1997). Managerial Entrenchment and Capital Structure Decisions. Journal of Finance, 52(4), 1444-1438. http://dx.doi.org/10.1111/j.1540-6261.1997.tb01115.x

Bertrand, M. \& Schoar, A. (2003). Managing with Style: The Effect of Mangers on Managers on Firm Policies. Quarterly Journal of Economics, 118(4), 1169-1208. http://dx.doi.org/10.1162/003355303322552775

Boehm, S. A., Dwertmann, D. J. G., Bruch, H., \& Shamir, B. (2015). The Missing Link? Investigating Organizational Identity Strength and Transformational Leadership Climate as Mechanisms That Connect CEO Charisma with Firm Performance. The Leadership Quarterly, 26(2), 156-171. http://dx.doi.org/10.1016/j.leaqua.2014.07.012

Brookman, J., \& Thistle, P. D. (2009). CEO Tenure, the Risk of Termination and Firm Value. Journal of Corporate Finance, 15(3), 331-344. http://dx.doi.org/10.1016/j.jcorpfin.2009.01.002

Buyl, T., Boone, C., Hendriks, W., \& Matthyssens, P. (2011). Top Management Team Functional Diversity and Firm 
Performance: The Moderating Role of CEO Characteristics. Journal of Management Studies, 48(1), 151-174. http://dx.doi.org/10.1111/j.1467-6486.2010.00932.x

Calori, R., Johnson, G., \& Sarnin, P. (1994). CEOs Cognitive Maps and the Scope of the Organization. Strategic Management Journal, 15(6), 437-457. http://dx.doi.org/10.1002/smj.4250150603

Certo, S. T., Lester, R. H., Dalton, C. M., \& Dalton, D. R. (2006). Top Management Teams: A Meta-Analytic $\begin{array}{llll}\text { Examination. Journal of } & \text { Management }\end{array}$ http://dx.doi.org/10.1111/j.1467-6486.2006.00612.x

Chen, H. L., Hsu, W. T., \& Huang, Y. S. (2010). Top Management Team Characteristics, R\&D Investment and Capital Structure in the IT Industry. Small Business Economics, 35(3), 319-333. http://dx.doi.org/10.1007/s11187-008-9166-2

Colbert, A. E., Brarrick, M. R., \& Bradley, B. H. (2014). Personality and Leadership Composition in Top Management Teams: Implications for Organizational Effectiveness. Personnel Psychology, 67(2), 351-387. http://dx.doi.org/10.1111/peps.12036

Cronqvist, H., Makhija, A. K., \& Yonker, S. E. (2012). Behavioral Consistency in Corporate Finance: CEO Personal and Corporate Leverage. Journal of Financial Economics, 103(1), 20-40. http://dx.doi.org/10.1016/j.jfineco.2011.08.005

Custodio, C., \& Metzger, D. (2014). Financial Expert CEOs: CEO's Work Experience and Firm's Financial Policies. Journal of Financial Economics, 114(1), 125-154. http://dx.doi.org/10.1016/j.jfineco.2014.06.002

Dechow, P., \& Sloan, R. (1991). Executive Incentives and the Time Horizon Problem. Journal of Accounting and Economics, 14(1), 51-89. http://dx.doi.org/10.1016/0167-7187(91)90058-S

Ferris, S. P., Jayaraman, N., \& Sabherwal, S. (2013). CEO Overconfidence and International Merger and Acquisition Activity. Journal of Financial and Quantitative Analysis, 48(1), 137-164. http://dx.doi.org/10.1017/S0022109013000069

Goel, A. M., \& Thakor, A. V. (2008). Overconfidence, CEO selection, and corporate governance. Journal of Finance, 63(6), 2737-2784. http://dx.doi.org/10.1111/j.1540-6261.2008.01412.x

Goldstein, R., Ju, N., \& Leland, H. (2001). An EBIT Based Model of Dynamic Capital Structure. Journal of Business, 74(4), 483-512. http://dx.doi.org/10.1086/322893

Graham, J. R., \& Harvey, C. (2001). The Theory and Practice of Corporate Finance: Evidence from the Field. Journal of Financial Economics, 60(2-3), 187-243. http://dx.doi.org/10.1016/S0304-405X(01)00044-7

Graham, J. R., Harvey, C. R., \& Puri, M. (2008). Managerial Attitudes and Corporate Actions. Working paper.

Graham, J. R., Harvey, C. R., \& Puri, M. (2013). Managerial Attitudes and Corporate Actions. Journal of Financial Economics, 109(1), 103-121. http://dx.doi.org/10.1016/j.jfineco.2013.01.010

Hackbarth, D. (2008). Managerial Traits and Capital Structure Decisions. Journal of Financial and Quantitative Analysis, 43(4), 843-882. http://dx.doi.org/10.1017/S002210900001437X

Hackbarth, D., Hennessy, C., \& Leland, H. (2007). Can the Tradeoff Theory Explain Debt Structure? Review of Financial Studies, 20(5), 1389-1428. http://dx.doi.org/10.1093/revfin/hhl047

Hambrick, D. C., \& Fukutomi, G. D. S. (1991). The Reasons of CEO's Tenure. Academy of Management Review, 16(4), 719-742. http://dx.doi.org/10.2307/258978 http://dx.doi.org/10.5465/AMR.1991.4279621

Hambrick, D. C., \& Mason, P. A. (1984). Upper Echelons: THE Organization as a Reflection of Its Top Managers. Academy of Management Review, 9(2), 193-206. http://dx.doi.org/10.2307/258434 http://dx.doi.org/10.5465/AMR.1984.4277628

Hambrick, D. C., Geletkanycz, M. A., \& Fredirckson, J. W. (1993). Top Executive Commitment to the Status Quo: Some Tests of Its Determinants. Strategic Management Journal, 14(6), 401-418. http://dx.doi.org/10.1002/smj.4250140602

Heaton, J. B. (2002). Managerial Optimism and Corporate Finance. Financial Management, 31(2), 33-45. http://dx.doi.org/10.2307/3666221

Hennessy, C., \& Whited, T. (2005). Debt dynamics. Journal of Finance, 60(3), 1129-1165. http://dx.doi.org/10.1111/j.1540-6261.2005.00758.x 
Hermalin, B. E., \& Weisbach, M. S. (1998). Endogenously Chosen Boards of Directors and Their Monitoring of the CEO. American Economic Review, 88(1), 96-118.

Hirshleifer, D. (1993). Managerial Reputation and Corporate Investment Decisions. Financial Management, 22(2), 145-160. http://dx.doi.org/10.2307/3665866

Hirshleifer, D., \& Thakor, A. V. (1992). Managerial Conservatism, Project Choice, and Debt. Review of Financial Studies, 5(3), 437-470. http://dx.doi.org/10.1093/rfs/5.3.437

Hu, C., \& Liu, Y. J. (2015). Valuing Diversity: CEOs' Career Experiences and Corporate Investment. Journal of Corporate Finance, 30(C), 11-31. http://dx.doi.org/10.1016/j.jcorpfin.2014.08.001

Jacquart, P., \& Antonakis, J. (2015). When Does Charisma Matter for Top-Level Leaders? Effect of Attributional Ambiguity. Academy of Management Journal, 58(4), 1051-1074. http://dx.doi.org/10.5465/amj.2012.0831

Jarboui, S., Forget, P., \& Boujelbene, Y. (2014). Inefficiency of Public Road Transport and Internal Corporate Governance Mechanisms. Case Studies on Transport Policy, 2(3), 157-167. http://dx.doi.org/10.1016/j.cstp.2014.05.004

Jensen, M. C., \& Meckling, W. H. (1976). Theory of the Firm: Managerial Behavior, Agency Costs and Ownership Structure. Journal of Financial Economics, 3(4), 305-360. http://dx.doi.org/10.1016/0304-405X(76)90026-X

Jensen, M., \& Zajac, E. (2004). Corporate Elites and Corporate Strategy. Strategic Management Journal, 25(6), 507-524. http://dx.doi.org/10.1002/smj.393

Kisfalvi, V., \& Pitcher, P. (2003). Doing What Feels Right: The Influence of CEO Character and Emotions on Top Management Team Dynamics. Journal of Management Inquiry, 12(1), 42-66. http://dx.doi.org/10.1177/1056492602250518

Landier, A., \& Thesmar, D. (2009). Contracting with Optimistic Entrepreneurs: Theory and Evidence. Review of Financial Studies, 22(1), 117-150. http://dx.doi.org/10.1093/rfs/hhn065

Leland, H., \& Toft, K. B. (1996). Optimal Capitals Structure, Endogenous Bankruptcy and the Term Structure of Credit Spreads. Journal of Finance, 51(3), 987-1019. http://dx.doi.org/10.1111/j.1540-6261.1996.tb02714.x

Lin, C., Lin, P., Song, F. M., \& Li, C. (2011). Managerial Incentives, CEO Characteristics and Corporate Innovation in China's Private Sector. Journal of Comparative Economics, 39(2), 176-190. http://dx.doi.org/10.1016/j.jce.2009.12.001

Malmendier, U., \& Tate, G. (2005). CEO Overconfidence and Corporate Investment. Journal of Finance, 60(6), 2661-2700. http://dx.doi.org/10.1111/j.1540-6261.2005.00813.x

Malmendier, U., \& Tate, G. (2008). Who Makes a Acquisitions? CEO Overconfidence and the Market's Reaction. Journal of Financial Economics, 89(1), 20-43. http://dx.doi.org/10.1016/j.jfineco.2007.07.002

Malmendier, U., Tate, G., \& Yan, J. (2011). Overconfidence and Early-Life Experiences: The Effect of Managerial Traits on Corporate Financial Policies. Journal of Finance, 65(5), 1687-1733. http://dx.doi.org/10.1111/j.1540-6261.2011.01685.x

Martínez-Campillo, A., \& Fernández-Gago, R. (2010). The Diversification-Performance Relationship in Spanish Firms: Does the CEO'S Behaviour Style Matter? European Research Studies, 11(1-2), 57-70.

Matta, E., \& Beamish, P. W. (2008). The Accentuated CEO Career Horizon Problem: Evidence from International Acquisitions. Strategic Management Journal, 29(7), 683-700. http://dx.doi.org/10.1002/smj.680

Miller, D. (1991). Stale in the Saddle: CEO Tenure and the Match between Organization and Environment. Management Science, 37(1), 34-52. http://dx.doi.org/10.1287/mnsc.37.1.34

Mohamed, E. B., Jarboui, S., Baccar, A., \& Bouri, A. (2015). On the Effect of CEO's Personal Characteristics in Transport Firm Value? A Stochastic Frontier Model. Case Studies on Transport Policy, 3(2), 176-181. http://dx.doi.org/10.1016/j.cstp.2015.01.001

Myers, S. (2001). Capital Structure. Journal of Economic Perspectives, 15(2), 81-102. http://dx.doi.org/10.1257/jep.15.2.81

Navaretti, G. B., Castellani, D., \& Pieri, F. (2014). Age and firm growth: Evidence from three European Countries. Small Business Economics, 43(4), 823-837. http://dx.doi.org/10.1007/s11187-014-9564-6

Nelson, T. (2003). The Persistence of Founder Influence: Management Ownership, and Performance Effects at Initial 
Public Offering. Strategic Management Journal, 24(8), 707-724. http://dx.doi.org/10.1002/smj.328

Nguyen, D. D., Hagendorff, J., \& Eshraghi, A. (2015). Which Executive Characteristics Create Value in Banking? Evidence from Appointment Announcements. Corporate Governance: An International Review, 23(2), 112-128. http://dx.doi.org/10.1111/corg.12084

Olsen, K. J., Dworkis, K. K., \& Young, S. M. (2014). CEO Narcissism and Accounting: A Picture of Profits. Journal of Management Accounting Research, 20(2), 241-267. http://dx.doi.org/10.2308/jmar-50638

Papadakis, V. M. (2006). Do CEOs Shape the Process of Making Strategic Decisions? Evidence from Greece. Management Decision, 44(3), 367-394. http://dx.doi.org/10.1108/00251740610656269

Pegels, C., \& Yang, B. (2000). Top Management Team Impact on Strategic Assets Accumulation Capabilities. Management Decision, 38(10), 694-710. http://dx.doi.org/10.1108/00251740010379740

Peterson, R. S., Martorana, P.V., Smith, D. B., \& Owens, P. D. (2003). The Impact of Chief Executive Officer Personality on Top Management Team Dynamics: One Mechanism by Which Leadership Affects Organizational Performance. Journal of Applied Psychology, 88(5), 795-808. http://dx.doi.org/10.1037/0021-9010.88.5.795

Peterson, S. J., Walumbwa, F. O., Byron, K., \& Myrowitz, J. (2009). CEO Positive Psychological Traits, Transformational Leadership, and Firm Performance in High-Technology Start-up and Established Firms. Journal of Management, 35(2), 348-368. http://dx.doi.org/10.1177/0149206307312512

Richard, O., \& Shelor, R. (2002). Linking Top Management Team Age Heterogeneity to Firm Performance: Juxtaposing Two Mid-Range Theories. International Journal of Human Resource Management, 13(6), 958-974. http://dx.doi.org/10.1080/09585190210134309

Roll, R. (1986). The Hubris Hypothesis of Corporate Takeovers. Journal of Business, 59(2), 197-216. http://dx.doi.org/10.1086/296325

Ryan, H. E., \& Wiggins, R. A. (2002). The Interactions between R\&D Investment Decisions and Compensation Policy. Financial Management, 31(1), 5-29. http://dx.doi.org/10.2307/3666319

Shleifer, A., \& Vishny, R. (1989). Management Entrenchment: The Case of Manager-Specific Investments. Journal of Financial Economics, 25(1), 123-139. http://dx.doi.org/10.1016/0304-405X(89)90099-8

Strebulaev, I. A. (2007). Do Tests of Capital Structure Theory Mean What They Say. Journal of Finance, 62(4), 1747-1787. http://dx.doi.org/10.1111/j.1540-6261.2007.01256.x

Strebulaev, I. A., \& Yang, B. (2013). The Mystery of Zero-Leverage Firms. Journal of Financial Economics, 109(1), 1-23. http://dx.doi.org/10.1016/j.jfineco.2013.02.001

Subrahmanyam, A. (2007). Behavioural Finance: A Review and Synthesis. European Financial Management, 14(1), 12-29. http://dx.doi.org/10.1111/j.1468-036x.2007.00415.x

Thomas, A. S., Litschert, R. J., \& Ramaswamy, K. (1991). The Performance Impact of Strategy-Manager Co-Alignment: An Empirical Examination. Strategic Management Journal, 12(7), 509-522. http://dx.doi.org/10.1002/smj.4250120704

Wales, W. J., Patel, P. C., \& Lumpkin, G. T. (2013). In Pursuit of Greatness: CEO Narcissism, Entrepreneurial Orientation, and Firm Performance Variance. Journal of Management Studies, 50(6), 1041-1069. http://dx.doi.org/10.1111/joms.12034

Weinzimmer, L. G. (1997). Top Management Team Correlates of Organizational Growth in a Small Business Context: A Comparative Study. Journal of Small Business Management, 35(3), 1-9.

Welch, I. (2004). Capital Structure and Stock Return. Journal of Political Economy, 112(1), 106-136. http://dx.doi.org/10.1086/379933

Wiersema, M. F., \& Bantel, K. A. (1992). Top Management Team Demography and Corporate Strategic Change. Academy of Management Journal, 35(1), 91-121. http://dx.doi.org/10.2307/256474 
Appendix 1. Personality traits of the 12 Zodiac Signs

\begin{tabular}{|c|c|c|}
\hline Zodiac & Date of Birth & Personality traits \\
\hline $\begin{array}{l}\text { Aries } \\
\text { (Fire) }\end{array}$ & $03 / 21-04 / 19$ & $\begin{array}{l}\text { Civic-minded, decisive, straightforward, acute, stubborn, vain, intensely emotional. } \\
\text { They have a high degree of tolerance. They have the willpower and the fight instinct to overcome hardships. Once they } \\
\text { come up with a goal in mind, they will be able to overcome all difficulties and move forward. In a new environment, } \\
\text { their pioneering spirits play the lead to open up new opportunities as leaders, with leadership. There is also an } \\
\text { aggressive side, their greatest joy is to set difficult things in motion against all odds. }\end{array}$ \\
\hline $\begin{array}{l}\text { Taurus } \\
\text { (Earth) }\end{array}$ & $04 / 20-05 / 20$ & $\begin{array}{l}\text { Reticent, determined, calm, cautious. } \\
\text { They have gentle personality and solid temperament; they are calm and at ease. Although they might get hesitant about } \\
\text { things, but once determined, will be able to move forward through perseverance. Patient and strong, they act carefully; } \\
\text { but there is also a stubborn side. They are dutiful to the duty they are entrusted with and will never give up halfway. }\end{array}$ \\
\hline $\begin{array}{l}\text { Gemini } \\
\text { (Air) }\end{array}$ & $05 / 21-06 / 21$ & $\begin{array}{l}\text { Smart, agile, resourceful, schizophrenic, arrogant, full of curiosity, good at communication. } \\
\text { They are sharp and quick. They have a strong sense of curiosity and thirst for knowledge, and are very sharp for new } \\
\text { ideas and new fashions. Clever, eloquent, they are strategists and speakers. They are able to handle accidents, through } \\
\text { calm observation, by being bold and being a responsible person. And often there will be some whim of ideas, which } \\
\text { they boldly hypothesize and carefully refute. }\end{array}$ \\
\hline $\begin{array}{l}\text { Cancer } \\
\text { (Water) }\end{array}$ & $06 / 22-07 / 22$ & $\begin{array}{l}\text { Loving, sensitive, imaginative, shrewd, subjective. } \\
\text { Emotionally rich, they have strong sensitivity for things. Diplomatic and humble, they are very aware of public } \\
\text { relations, but they also have strong defense instinct for domestic affairs, unwilling to let their privacy be disturbed. } \\
\text { Generally gentle and introverted, but they will never bow to the evil forces. Enthusiastic for community, they have a } \\
\text { strong sense of self and respect people who stand their grounds. They are nostalgic and traditional. }\end{array}$ \\
\hline $\begin{array}{l}\text { Leo } \\
\text { (Fire) }\end{array}$ & $07 / 23-08 / 22$ & $\begin{array}{l}\text { Self-confident, self-complacent, strong planning and leadership skills, not flexible, smart, energetic, strong-willed, } \\
\text { passionate, courageous, impatient, careless. } \\
\text { Honest, quite dignified. They like to use their own charm and talent to create a whole new world, and are eager for } \\
\text { positions of power. They do things honorably, going all out, and are disgusted by despicable villainy acts. They have } \\
\text { acting talent, and are self-confident, almost narcissistic. Also, they attract the masses with their generous hearts. } \\
\text { However, they tend to have emotion swings, and often feel lonely. }\end{array}$ \\
\hline $\begin{array}{l}\text { Virgo } \\
\text { (Earth) }\end{array}$ & $08 / 23-09 / 22$ & $\begin{array}{l}\text { Calm, attentive, serious, ethical, picky (perfectionism). } \\
\text { Diligent, meticulous, they like the contact with the community, act rationally, and are the type that contributes to } \\
\text { society. They are considerate to people, work efficiently and are commanding; but sometimes they are too careful and } \\
\text { miss the big picture. However, generally, they are able to plan and get things done in practice, and they always work in } \\
\text { good conscience. They are thoughtful, full of critical spirit, and can easily become a sharp critic. They have strong } \\
\text { moral values. }\end{array}$ \\
\hline $\begin{array}{l}\text { Libra } \\
\text { (Air) }\end{array}$ & $09 / 23-10 / 23$ & $\begin{array}{l}\text { Mild, calm, intelligent, indecisive. } \\
\text { Balanced and sensible. They have a good sense of balance and fair judgment, good coordination, and can often mediate } \\
\text { opposing views. Always on the logic and strategy, they absolutely use no violence to resolve things, but with clever } \\
\text { diplomacy, and find balance for conflicting rights and interests. They are indecisive but not hesitant, diplomatic, have } \\
\text { social talents, and can easily win favor from those in power. }\end{array}$ \\
\hline $\begin{array}{l}\text { Scorpio } \\
\text { (Water) }\end{array}$ & $10 / 24-11 / 22$ & $\begin{array}{l}\text { Intelligent, deep, hard-working, bad at communication, courageous, lack foresight and hindsight. } \\
\text { Strong impulsive, they have energy and courage, and do not fear difficult. Observant, they are often able to discern the } \\
\text { truth of things and have unique insights. When acting, they use destructive and innovative ways. They are full of } \\
\text { mystery. Never actively harm anyone, but if hurt they will hit back in retaliation, by taking appropriate response } \\
\text { measures. They are relentless on spiritual and material needs and their reactions to love and hate are very strong. }\end{array}$ \\
\hline $\begin{array}{l}\text { Sagittari } \\
\text { us (Fire) }\end{array}$ & $11 / 22-12 / 21$ & $\begin{array}{l}\text { Freedom-loving, focused, calm, witty, weak analytical skills. } \\
\text { Frank and cheerful, they have high expectations for justice and truth, and want to have knowledge and experience more } \\
\text { than ordinary people. Focused on spiritual life, they like philosophical thinking and put human welfare and global } \\
\text { progress far above individual needs, but easily fall into empty optimism. Bold and adventurous, with their love of } \\
\text { freedom, no matter under what circumstances they wish to remain independent in spirit and in action. }\end{array}$ \\
\hline $\begin{array}{l}\text { Capricor } \\
\mathrm{n} \\
\text { (Earth) }\end{array}$ & $12 / 22-01 / 19$ & $\begin{array}{l}\text { Stubborn, arbitrary, conservative, patient and strong, unyielding, practical (realistic), conceited. } \\
\text { Full of wisdom, thoughtful. They have a high degree of endurance and can patiently wait under harsh realities. To make } \\
\text { plans work, they can get through a long period of arduous preparation, never letting up. Thinking deep, they know well } \\
\text { about human nature. They may not be agile, but they will persevere. Rigorous and practical, they easily become lonely. } \\
\text { They never hide their self-interest, but generally can still obtain trust of those in power. They have a sense of social } \\
\text { responsibility and know how to weigh advantages and disadvantages to build a place for themselves in the world. }\end{array}$ \\
\hline $\begin{array}{l}\text { Aquarius } \\
\text { (Air) }\end{array}$ & $02 / 20-02 / 18$ & $\begin{array}{l}\text { Arbitrary, bold and courageous, without foresight. } \\
\text { Independent and perseverant, the Aquarius people often have some radical and innovative insights; they are the } \\
\text { characters of the new era, full of universal love and awareness of democracy, and can break and ethnic differences and } \\
\text { social class to cultivate true friendship. Against some conventional concepts, in order to be loyal to their own belief, } \\
\text { they will try to radically resist. They are the type of people that tend to form political parties or groups and initiate } \\
\text { movements for a common purpose. }\end{array}$ \\
\hline $\begin{array}{l}\text { Pisces } \\
\text { (Water) }\end{array}$ & $02 / 19-03 / 20$ & $\begin{array}{l}\text { Smart, sensitive, self-sacrificial, idealistic, indecisive, problem-evading (challenges). } \\
\text { Talented and like to dream, the Pisces people are dependent but can be adaptive to different environments and positions. } \\
\text { They are full of creative and artistic talent, and tend to indulge in poetic plots and dreams, believing that true happiness } \\
\text { come from being one with the spiritual world. Since they choose to stay away from earthly life, they will not have much } \\
\text { success in the material world. Compassionate and self-sacrificing, they are especially sympathetic for the weak and } \\
\text { unfortunate people in the society. }\end{array}$ \\
\hline
\end{tabular}

Data Source: compiled from www.yahoo.com.tw and www.msn.com.tw. 
Appendix 2. Classifications of Zodiac Signs and behavioral traits

\begin{tabular}{|c|c|c|c|c|c|}
\hline \multirow[t]{2}{*}{ Classifications } & \multicolumn{2}{|c|}{ Positive polarity } & \multicolumn{2}{|c|}{ Negative polarity } & \multirow[t]{2}{*}{ Behavioral traits } \\
\hline & Fire elemental & Air elemental & Earth elemental & Water elemental & \\
\hline $\begin{array}{l}\text { Cardinal } \\
\text { (Beginning of each } \\
\text { season) }\end{array}$ & Aries & Libra & Capricorn & Cancer & $\begin{array}{l}\text { Leadership; innovative; stubborn; } \\
\text { positive; creative; ambitious; } \\
\text { passionate; independent; } \\
\text { autocratic; courage to lead. }\end{array}$ \\
\hline $\begin{array}{l}\text { Fixed } \\
\text { (Middle of each } \\
\text { season) }\end{array}$ & Leo & Aquarius & Taurus & Scorpio & $\begin{array}{l}\text { Stable; stubborn; self-centered; do } \\
\text { not like change; intensely } \\
\text { emotional; see things in black and } \\
\text { white and are difficult to } \\
\text { communicate or negotiate with; } \\
\text { perseverant; positive; reliable; } \\
\text { loyal. }\end{array}$ \\
\hline $\begin{array}{l}\text { Mutable } \\
\text { (End of each } \\
\text { season) }\end{array}$ & Sagittarius & Gemini & Virgo & Pisces & $\begin{array}{l}\text { Ingenuous and attentive; smart } \\
\text { and quick; innovative; emphasize } \\
\text { on integration of different ideas; } \\
\text { easy-going; adaptive; diverse; } \\
\text { sensitive and fickle; } \\
\text { compassionate; intuitive; quick to } \\
\text { absorb new knowledge and new } \\
\text { ideas. }\end{array}$ \\
\hline \multirow{6}{*}{ Personality Traits } & Proactive & Optimistic & Safe & Affectionate & \\
\hline & Leadership & Smart & Stable & Family-oriented & \\
\hline & Motivated & Witty & Realistic & Planner & \\
\hline & Freedom-loving & Innovative & $\begin{array}{l}\text { Stubborn } \\
\text { Thrifty }\end{array}$ & Attentive & \\
\hline & Positive traits: & & \multicolumn{2}{|l|}{ Negative traits: } & \\
\hline & $\begin{array}{l}\text { Proactive, optimi } \\
\text { good at communi } \\
\text { innovative, harm } \\
\text { humanitarian. }\end{array}$ & $\begin{array}{l}\text { tic, independent, } \\
\text { cation, } \\
\text { nious, }\end{array}$ & \multicolumn{2}{|c|}{$\begin{array}{l}\text { Passive, pessimistic, sensitive of } \\
\text { security, analytical, focused, cautious, } \\
\text { easily-influenced, ethical, consistent. }\end{array}$} & \\
\hline
\end{tabular}

Data Source: Compiled from astrological encyclopedia, www.coden.com.tw/libary/, www.yahoo.com.tw, and www.msn.com.tw. 